\title{
Morphological Features of the Apical Region in the Principal Cells of Mongrel Dog Epididymis
}

\author{
Características Morfológicas de la Región Apical de las Células Principales del Epidídimo del Perro Mongrel
}

\author{
"Bruno Cesar Schimming \& **arlos Alberto Vicentini
}

SCHIMMING, B. C. \& VICENTINI, C. A. Morphological features of the apical region in the principal cells of mongrel dog epididymis. Int. J. Morphol., 26(1):149-153, 2008.

SUMMARY: The epithelial principal cells are the predominant cell type of the epididymis. These cells have been shown to be both secretory and endocytic cells. The apical region of the cytoplasm of principal cells in the mongrel dog are located close to the cell apex and tubular lumen, and shown microvilli at the luminal border and present a endocytic apparatus, that consists of coated pits and vesicles, endosomes of varying size, multivesicular bodies, and lysosomes. The endosomes, multivesicular bodies and lysosomes contained the electron-dense patches. These results suggest that principal cells of the epididymis in the dog as possess a highly developed endocytic apparatus play a role in endocytosis. These cells function are similarly to the related in other mammals, in performing endocytosis.

KEY WORDS: Epididymis, Dog, Principal cells, Ultrastructure.

\section{INTRODUCTION}

The epididymis represents the main segment of the excurrent ducts in mammals. Maturation of spermatozoa occurs during their passage through the epididymis (Amann et al., 1993; Cooper, 1995; Smithwick \& Young, 1999). Robaire \& Hermo (1988) claimed that the epididymis in mammals is the site where the reabsorption of the testicular fluid, and secretory activities occur, benefiting the maturational process of the spermatozoa. These functions including absorption, synthesis, and secretion, that created an appropriate luminal environment for the acquisition of fertilizing ability and motility of spermatozoa (Hinton, 1990; Turner, 1991). The epithelium lining the epididymis of mammals, because of its role in providing a suitable milieu for the maturation of spermatozoa (Orgebin-Crist, 1969), has been the object of numerous cytological and histochemical investigations (Robaire \& Viger, 1995; Robaire \& Hermo; Schimming \& Vicentini, 2005).

The epididymal epithelium contains several cell types: principal, basal, clear, narrow, halo, and apical cells (Serre \& Robaire, 1998). The principal, basal, and halo cells appeared throughout the epididymis. The clear cells are not present in the initial segment of the rat epididymis (Moore \& Bedford, 1979). Apical cells have been previously described in the initial segment in the adult rat epididymis. Narrow cells has been found only in the initial segment too (Adamali \& Hermo, 1996).

The epithelial principal cells are the predominant cell type of the epididymis. They are tall columnar cells, that extend from basement membrane to luminal border of the epithelium. These cells are very active with respect to transport and secretion of small organic molecules, protein synthesis and secretion, and absorption of both fluid and particulate matter (Robaire \& Hermo). To these authors, these cells have been shown to be involved in the secretion of a variety of substances such as ions, small organic molecules, and glycoproteins, which have been suggested to have a role in sperm maturation. Therefore, endocytosis is also an event in the life of principal cells, where tracers were endocytosed by these cells. Tracers appeared in coated pits and large coated vesicles, endosomes of varying sizes, multivesicular bodies, and lysosomes (Hermo, 1995).

Based on previous information, the present morphological examination attempts to described features on apical cytoplasmic of the epididymal principal cells in the mongrel dogs to correlate some characteristics with 
functions previously described for epididymis of other mammals.

\section{MATERIAL AND METHOD}

Epididymal tissues were obtained from five mature mongrel dogs (Canis familiaris, L.). Small pieces were collected from the initial, middle and terminal segments of the epididymis. The tissues were fixed by immersion in 2,5\% glutaraldehyde in $0.1 \mathrm{M}$ phosphate buffer at $\mathrm{pH} 7.4$, for 24 $\mathrm{h}$, at $4^{\circ} \mathrm{C}$. Following primary fixation, the pieces were washed three times in the same buffer, post-fixed for $2 \mathrm{~h}$, in $1 \%$ osmium tetroxide $\left(\mathrm{OsO}_{4}\right)$ in $0.1 \mathrm{M}$ phosphate buffer, dehydrated through a graded series of ethanol solutions and embedded in Araldite resin. Semithin sections were stained with methylene blue and azure B. Ultrathin sections were collected on uncoated copper grids, contrasted with uranyl acetate and lead citrate, and examined at a Philips EM 301 electron microscope (Philips, Eindhoven, the Netherlands), in Electron Microscopy Center, Biosciences Institute of Botucatu, UNESP.

\section{RESULTS}

The apical region of the cytoplasm of the principal cells of mongrel dogs epididymis are located close to the cell apex and tubular lumen, and shown microvilli at the luminal border (Figs. 1, 3 and 4). Each microvillus is a fingerlike extension of cell membrane. Principal cells contained a variable number of apically located endosomes of varying size (Figs. 1, 3 and 4).

In the surrounding cytoplasm of the apical region, numerous smaller vesicular elements with no apparent content were also evident such as small coated and uncoated vesicles (Figs. 1, 2 and 3). Coated pits were seen on the apical cell surface and nearby were large coated vesicles (Figs. 1, 2 and 4). Therefore, multivesicular bodies, and lysosomes as seen in the apical region. Some endosomes, multivesicular bodies and lysosomes contained the electrondense patches. These multivesicular bodies usually are ovoid in shape, and seen deeper in the apical cytoplasm (Fig. 3).

Certainly one of the most striking cytological features of the epithelial cells under consideration is the presence of numerous uncoated and coated vesicles concentrated in their apical cytoplasm (Figs. 1, 2 and 3). These structures characterized a endocytic apparatus. Profiles of cisternae of endoplasmic reticulum and mitochondria are scattered throughout the cytoplasm, near the endocytic apparatus (Fig. 2). These endocytic apparatus were a distinctive feature of apical region of the principal cells.

\section{DISCUSSION}

The present study described features on apical cytoplasmic of the epididymal principal cells in the mongrel dogs with the aim to correlate some characteristics with functions previously described for epididymis of other mammals. The principal cells of the mongrel dog epididymis exhibited ultrastructures features in the apical cytoplasm, that are common to the stereociliated cells and morphological peculiarities of a cell type that is involved in a absorption and secretion process.

Substances may diffuse through cell membranes, or they may be transported by special membrane protein transport system or channels (e.g. ions). Other material from the extracellular space, as well as surface membrane, may be incorporated into the cell by invagination of the cell surface in a process termed endocytosis. The invaginated cell membrane fuses to form an endocytotic vesicle or endosome, which is a small, sealed, spherical membranebound body. The membrane and any material incorporated into such a vesicle can then be processed within the cell (Stevens \& Lowe, 1997). To these authors, there are two main vesicles involved in transport of substances into cells, that are derived from surface membrane invaginations and are called coated pits. Coated pits are invaginations braced by special membrane-associated proteins and are used to bring material into the cell for further processing. In many instances special receptor proteins are present in the cell membrane which can bind to specific substances outside the cell and draw them inside in a process termed receptormediated endocytosis. Coated vesicles may also develop from other internal membrane systems inside cells.

The apical region of epididymal principal cell of the dog showed an endocytotic apparatus with endosomes, multivesicular bodies, lysosomes, coated and uncoated pits and vesicles. Probably, as related by Stevens \& Lowe, the coated pits became coated vesicles in the cytosol. They drive progressive invagination of the pit to form coated vesicles, as seen in this study. The coated pits are seen in the luminal border. A coated pit is braced by a coat of protein molecules and bears surface receptors that bind specific extracellular ligands. In most cases the coat protein is clathrin.

Turner (1984) postulated that resorption is an important aspect of epididymal control of the intraluminal 

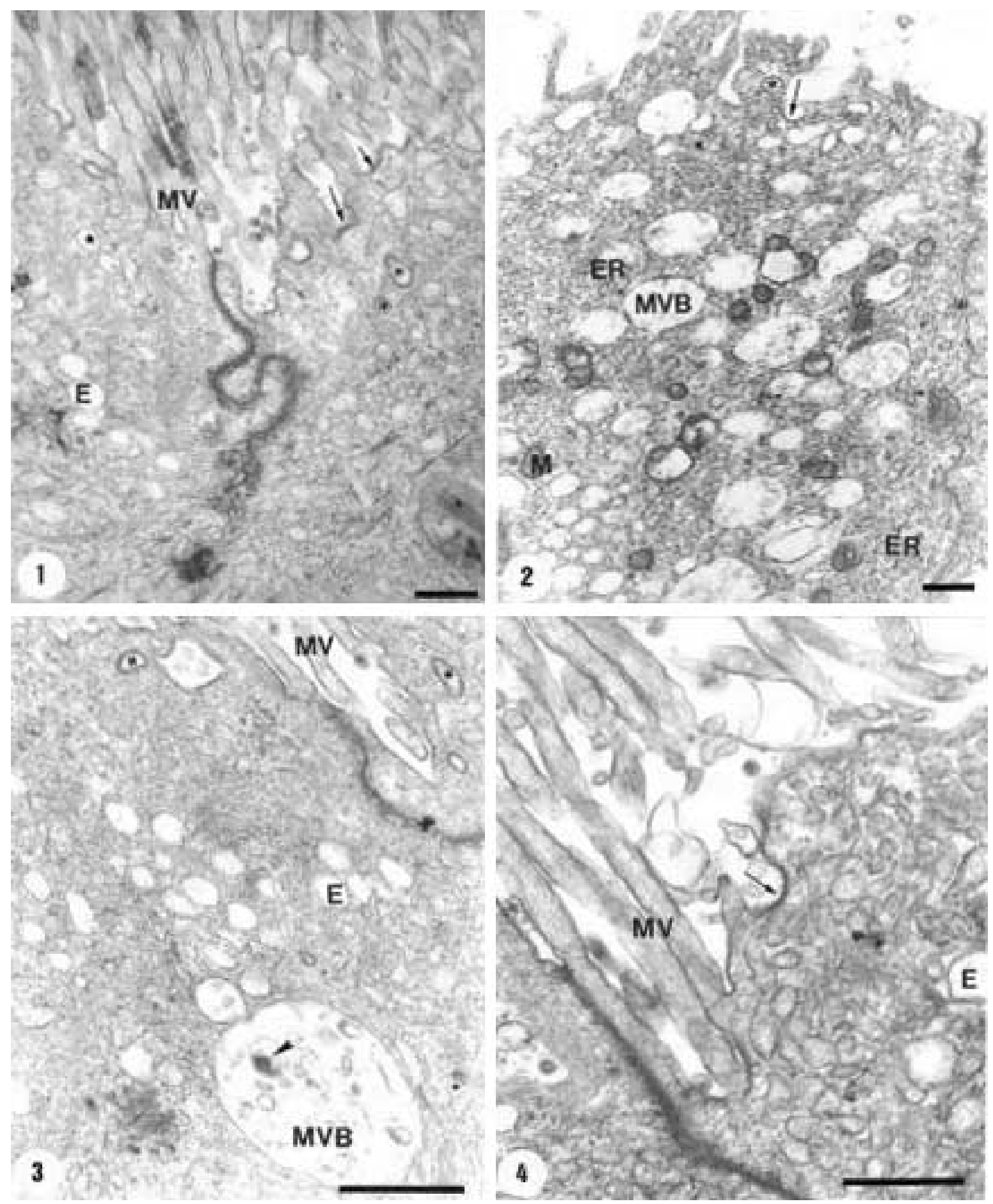

Figs. 1-4. The apical region of principal cells. Endosomes (e) of varying size are evident. Some multivesicular bodies (mvb) are associated with clumps or patches of electron-dense granular material (arrowheads). Smooth surfaced, empty looking secretory vesicles (stars) are also evident. Coated pits (arrows) and vesicles (asteriks) are associated with the cell surface. Profiles of cisternae of endoplasmic reticulum (er) and mitochondria $(\mathrm{m})$ are scattered throughout the cytoplasm. Microvilli (mv) in the luminal border can be seen. Note the epithelial cell junctions. Figs. 1 and 2 - x27500, Figs. 3 and 4 - x50000.

environment. Many proteins have been shown to be internalized by cells through receptor-mediated endocytosis, a process in which the protein binds to a specific receptor on the cell surface and is subsequently internalized through clatrin-coated pits along the plasma membrane (Goldstein et al., 1979; Steinman et al., 1983). 
Hermo \& Melo (1987) observed in the principal cells of the vas deferens in the rat, a apical cytoplasmic region of the principal epithelial, which contains an abundance of vesicular elements of which only a few are involved in endocytosis of cationic ferritin and native ferritin. The internalization of both tracers from the lumen occurs predominant at the level of coated pits. The tracers are seen in coated pits, large coated vesicles, apical tubules, pale and dense multivesicular bodies, and secondary lysosomes. The principal cells of the dog epididymis showed coated pits and vesicles, multivesicular bodies, endosomes and lysosomes, that can suggest that are similar to that described by the rat.

The observation of the several smooth surfaced empty looking secretory vesicles in the apical cytoplasm of the epididymal principal cells in the dogs, resembles a similar finding in the principal cells of the epithelial lining of the adult rats epididymis (Hermo). Hermo \& Melo showed various vesicular elements that are not involved in the internalization of tracers to the principal cells. The exact role of these various vesicular structures remains to be clarified. It is possible, since these epithelial cells are known to be secretory cells, that some of these vesicles may be involved in the transport of secretory material or membrane glycoproteins from the Golgi apparatus to the cell surface.

Principal cells of epididymis of adult rats endocytosed tracers introduced into the lumen of the duct (Hermo). Thus, the endocytic apparatus observed in the epididymal principal cells of mongrel dogs, suggest that cells has a function similarly to epididymal principal cells of other mammals (Hermo et al., 1994; Hermo).

These results suggest that principal cells of the epididymis in the dog as possess a highly developed endocytic apparatus in the apical cytoplasm, can be involved in absorptive or endocytosis role. The cells function are similarly to principal cells related in other mammals as rats, in performing endocytosis (Hermo).

It has been suggested that endocytosis and exocytosis occur simultaneously between epithelial cells and the fluid phase of the luminal content (Goyal, 1985; Wystub et al., 1989). Based on the morphological findings, Schimming \& Vicentini, postulated that the principal cells of the dog epididymis are also secretory cells.

SCHIMMING, B. C. \& VICENTINI, C. A. Características morfológicas de la región apical de las células principales del epidídimo del perro mongrel. Int. J. Morphol., 26(1):149-153, 2008.

RESUMEN: Las células epiteliales principales son el tipo de célula que predominan en el epidídimo. Estas células han demostrado ser secretoras y endocíticas. La región apical del citoplasma de las células principales en el perro Mongrel, se encuentran muy cerca del ápice celular y lumen tubular, mostrando microvellosidades en el límite luminal y un aparato endocítico, el que consiste en depresiones recubiertas y vesículas, endosomas de diversos tamaños, cuerpos multivesiculares y lisosomas. Los endosomas, cuerpos multivesiculares y lisosomas contienen gránulos electrodensos. Estos resultados sugieren que las células principales del epidídimo, en el perro, poseen un aparato endocítico altamente desarrollado que juega un importante rol en la endocitosis. Estas células funcionan de manera similar a la correspondiente en otros mamíferos, en el desempeño de endocitosis.

PALABRAS CLAVE: Epidídimo; Perro; Células principales; Ultraestructura.

\section{REFERENCES}

Amann, R. P.; Hammerstedt, R. H.\& Veeramachaneni, D. N. R. The epididymis and sperm maturation: a perspective. Reprod. Fertil. Dev., 5:361-81, 1993.

Adamali, H. I. \& Hermo, L. Apical and narrow cells are distinct cell types differing in their structure, distribution, and functions in the adult rat epididymis. J. Androl., 17(3):208-22, 1996.

Cooper, T. G. Role of the epididymis in mediating changes in the male gamete during maturation. In: Renin Angiotensin Systems. (Eds. K. Mukhopadhay, M. K. Raizada) Plenum Press, New York, 87-101, 1995.
Goldstein, J. L.; Anderson, R. G. W. \& Brown, M. S. Coated pits, coated vesicles and receptor mediated endocytosis. Nature, 279:679-85, 1979.

Goyal, H. O. Morphology of the bovine epididymis. Am. J. Anat., 172:155-72, 1985.

Hermo, L. Structural features and functions of principal cells of the intermediate zone of the epididymis of the adult rats. Anat. Rec., 242:515-30, 1995.

Hermo, L. \& Melo, V. Endocytic apparatus and transcytosis in epithelial cells of the vas deferens in the rat. Anat. 
Rec., 217:153-63, 1987.

Hermo, L.; Oko, R. \& Morales, C.R. Secretion and endocytosis in the male reproductive tract: a role in sperm maturation. Int. Rev. Cytol., 154:105-89, 1994.

Hinton, B. The testicular and epididymal luminal amino acid micro environment in the rat. J. Androl., 11:498-505, 1990.

Moore, H.D.M. \& Bedford, J. M. The differential absorptive activity of epithelial cells of the rat epididymis before and after castration. Anat. Rec., 193:313-28, 1979.

Orgebin-Crist, M.C. Studies on the function of the epididymis. Biol. Reprod., 1:155-75, 1969.

Robaire, B. \& Hermo, L. Efferent ducts, epididymis, and vas deferens: structure, functions, and their regulation. In: Knobil E., Neill J. (eds.), The physiology of reproduction, New York: Raven Press, pp. 999-1080, 1988.

Robaire, B. \& Viger, R.S. Regulation of epididymal epithelial cell functions. Biol. Reprod., 52:226-36, 1995.

Serre, V. \& Robaire, B. Segment-specific morphological changes in aging brown Norway rat epididymis. Biol. Reprod., 58:497:513, 1998.

Schimming, B. C. \& Vicentini, C.A. Zinc iodide-osmium tetroxide (ZIO) reactive Golgi apparatus in the principal cells of dog epididymal epithelium. Int. J. Morphol., 23(4):337-44, 2005.

Smithwick, E. B. \& Young, L. G. Immunohistochemical localization of epididymal secretory glycoprotein EP1 in the adult male chimpanzee. Tissue \& Cell, 31(1):5465, 1999.

Steinman, R. M.; Mellmann, I. S.; Muller, W. A. \& Cohn, Z. A. Endocytosis and recycling of plasma membrane. $J$. Cell Biol., 96:1-7, 1983.

Stevens, A. \& Lowe, J. Human histology. London, Mosby, 1997. pp. 12-4.

Turner, T. T. On the epididymis and its role in the development of the fertile ejaculate. J. Androl., 16(4):292-8, 1991.

Turner, T. T. Resorption versus secretion in the rat epididymis. J. Reprod. Fert., 72:509-14, 1984.
Wystub, T.; Branscheid, W. \& Paufler, S. Investigations on the surface epithelium of rete testis and epididymis by scanning electron and light microscopic studies in boars. I. Rete testis and ductuli efferentes. Dtsch. Tierärztl. Wschr., 96:384-98, 1989.

\section{Correspondence to:}

Prof.

Dr. Bruno Cesar Schimming

Department of Veterinary Medicine

Agrarian Sciences Faculty

University of Marília

Av. Hygino Muzzi Filho, 1001

CEP17525-902

Marília, São Paulo,

BRAZIL

\section{Email: brunoidish@terra.com.br}

Received: 10-09-2007

Accepetd: 03-12-2007 
